\title{
Editorial
}

\section{As Novas Diretrizes Curriculares e a Cartilha do SUS: Alfabetizando Professores do Curso Médico - Paradoxos \& Contradições}

\author{
The New SUS Curricular Guidelines and \\ Handbook: Teacher Training for the Medical \\ Course - Paradoxes and Contradictions
}

Em 10 de setembro de 2013, um telejornal de grande penetração informava que cientistas brasileiros apresentaram, na 1ํㅡㄹ Conferência Nacional de Mudanças Climáticas Globais, em São Paulo (SP), "um estudo que apontava uma elevação média da temperatura no Brasil". Em função do rigor científico do estudo, não foi estabelecida nenhuma correlação com os "movimentos de rua", ocorridos em junho, e nem com a Medida Provisória no 621, do mês seguinte desse mesmo ano. Não precisamos, também, recorrer a Boltzmann para entender a relação direta entre "movimentos e temperatura", pois todos percebemos que "as temperaturas nas ruas, no sistema de transporte público, na saúde, na educação e na política" se elevaram muito acima da metáfora climática. Em muitos momentos, com incêndios! Quase todos tivemos de nos aluir de nossa "zona de conforto"! E aqui já detectamos o primeiro paradoxo: os meses mais "quentes" do ano no Brasil foram junho e julho! Os mais otimistas poderiam imaginar que estávamos de mudança para o Hemisfério Norte!

Um ano depois, com "o calor" mais restrito às "Arenas padrão Fifa", podemos refletir com uma fingida serenidade sobre os acontecimentos destes turbulentos trezentos e muitos dias e noites. E, para não "tropeçar" em "canteiros de obras", em "metrônibus em greve", em "metáforas tsunâmicas" ou em "reservatórios vazios", vamos circunscrever este editorial ao Parecer CNE/CES no 116/2014, homologado em 5 de junho de 2014 por despacho do ministro de Estado da Educação, aprovando as novas "Diretrizes Curriculares Nacionais para o curso de graduação em Medicina", com publicação no Diário Oficial da União nº 107, de 6 de junho de 2014.

O primeiro aspecto que chama atenção no conjunto do documento ora homologado é sua extensão, quando comparada à do equivalente Parecer CNE/CES no 1.133/2001. Para efeito de comparações, excluímos deste último as páginas referentes aos cursos de Enfermagem e Nutrição. Neste Parecer, do cabeçalho padrão até a "Decisão da Câmara de Ensino Superior", o conteúdo do Relatório ocupou quatro páginas. No atual, foram necessárias 32 páginas. As DCN para Medicina em 2001 continham 14 artigos distribuídos em cinco páginas. As recém-homologadas, 41 artigos, em 15 páginas. Pode-se argumentar, com suas razões, que se trata de meros detalhes, irrelevantes, pois o que deve ser considerado é o conteúdo e sua adequação histórica. Entretanto, se levarmos em conta o tempo de formulação/elaboração, tropeçamos em um possível segundo paradoxo: aquele documento enxuto e pioneiro exigiu quase cinco anos de debates, embates, oficinas, encontros interprofissionais e interinstitucionais para ser concluído. O atual foi gestado, elaborado e concluído em apenas 180 dias (meio ano!). Desde Einstein, esta história de espaço \& tempo só complica a vida da gente!

Outro ponto que parece se afogar nas "águas da contradição" está no fato de as DCN de 2001 resultarem da aproximação entre as profissões da área da saúde, tendo sido possível pactuar as mesmas competências/habilidades gerais para quase todas as formações dessa 
área, rompendo o isolamento onipotente da Medicina. Uma conquista que augurava a superação de barreiras históricas e a integração dos cursos da área da saúde, tão claramente necessárias ao trabalho em equipe e ao enfrentamento da transição demográfica e epidemiológica, com o envelhecimento populacional e a prevalência das condições crônicas sobre as condições agudas no espectro sanitário do País. Já as DCN em formato especial para a Medicina, ora em vigência e nas "turvas águas" do "Mais Médicos", parecem reforçar a ideia de que "a medicina é diferente", necessita um "tratamento diferenciado", uma "atenção particular", descolada das demais formações...

Sem dúvida, o documento possui méritos inquestionáveis, avançando em conceituações indispensáveis, apontando "o cuidado como modo de ser essencial" para todos e, especialmente, para os médicos! Corrige omissões graves das DCN de 2001, como a da "saúde mental" e da "urgência/emergência", particularmente no internato, e, pela primeira vez, exige das instituições "um programa permanente de formação e desenvolvimento do seu corpo docente", além de conectar a residência médica com a graduação e tentar "cortar o nó górdio" que dificulta a integração ensino-serviço ao propor "regime de parcerias por meio de contrato organizativo da ação pública ensino-saúde".

A leitura cuidadosa deste documento descortina e aponta um sem-número de paradoxos e contradições, como, por exemplo, ao propor a "demolição das fronteiras entre pesquisa e ensino-aprendizagem" com base na assertiva de que "se as pesquisas, para produzirem as respostas necessárias, têm de ser construídas interdisciplinarmente, o mesmo deve se aplicar ao processo de ensino-aprendizagem". No entanto, no mundo real da universidade, com as exceções que confirmam a regra, uma das primeiras decisões que o docente toma ao galgar o "pódio de pesquisador" é se livrar do ensino de graduação, na melhor das hipóteses delegando-o a um de seus orientandos menos talentoso! Como aprender se quem pode ensinar se recusa a isto? E ninguém, em sã consciência, irá afiançar que o fantástico sistema de pontuação da Capes não está reforçando este comportamento! Pode ser, também, uma influência "delfiniana" tardia: "primeiro o bolo tem que crescer para depois ser dividido!" Enquanto isto, os graduandos — tal qual o povão - esperam!

A erudita riqueza do documento, a tentativa de alfabetizar a escola médica utilizando este documento como uma "cartilha do SUS" e a grave conjuntura da saúde e da educação médica no País não podem representar um impedimento à reflexão e contextualização destes elementos com o ideário do "Mais Médicos" e suas raízes motivadoras. Ressalvando os nossos limitados conhecimentos sobre a Homeopatia e correndo todos os riscos que as analogias trazem em seu bojo, ousaremos supor que foi efetuado um diagnóstico de uma doença/desequilíbrio no "organismo Brasil" cujo "fator causal" foi identificado como "médico": um conjunto de sintomas expressados por "escassez", "má distribuição", "especialização", "elitismo", "corporativismo" e "inadequação", entre outros. Como na Homeopatia, "o médico" constituía o "veneno que desequilibrava o organismo", e o tratamento teria que obedecer ao princípio homeopático do "semelhante cura o semelhante". Por isto, "o médico" representaria "o abastecimento da força vital" que reequilibraria o organismo. Porém, por "uma certa confusão no emprego do método", optou-se pelo "tratamento de ataque" alopático, utilizando-se o mesmo "princípio ativo": "mais médicos para o Brasil!". Assim, nos próximos anos, o "organismo Brasil" deverá ser "inundado" por médicos! Muitos com elevado grau de contaminação retórica e vítimas de deformação curricular, pois certamente não conseguirão que os "pesquisadores interdisciplinarizantes" (com seus GPS) desçam do pódio e ajudem meros graduandos a "navegar" com segurança, competência e desenvoltura inter e transdisciplinarmente!

Por falar em navegação, fizemos um rápido e diagonal percurso inter e transdisciplinar (sem GPS) pelos resumos dos trabalhos publicados neste número da RBEM e ficamos encantados pela coincidência e até congruência dos conceitos e conteúdos "pescados" aqui e os explicitados e lapidados em toda a extensão do homologado Parecer CNE/CES nº 116/2014! Lançando para a plateia, eis: "construção da autonomia"; "autonomia como reconhecimento de valor"; "relacionamentos"; "frustração do estudante ante a realidade sanitária"; "competências e habilidades"; "avaliação do conhecimento - tipologia de Bloom"; "conhecimento e análise"; "conhecimento de ética médica"; "religiosidade no contexto médico: entre a receptividade e o silêncio"; "cenários de prática e métodos de ensino"; "atenção pré-hospitalar e suporte básico de vida para ingressantes"; "ensino de anatomia humana: métodos x expectativas"; "escolha das especialidades médicas"; "inventário de empatia: tomada de perspectiva, flexibilidade interpessoal, altruísmo, sensibilidade afetiva"; "realidade do internato: conhecimento do preceptor"; "estágio de urgência/ emergência: UPA"; "projeto terapêutico singular: saúde mental — visita domiciliar"; "humanização: doutores palhaços no Icesp — habilidades de comunicação e ampliação da visão do paciente"; "o futuro da prática médica na reflexão discente: problematizando a realidade"; "reformas na educação médica: desafios atuais - Angola e mundo"; "feminização da medicina: impactos, preconceitos e desafios".

Francisco Barbosa Neto

Diretor Vice-Presidente da Abem 